\title{
Expression of target genes of nuclear factor E2-related factor 2 in the liver of dairy cows in the transition period and at different stages of lactation
}

\author{
D. K. Gessner, ${ }^{*}$ G. Schlegel, ${ }^{*}$ J. Keller, ${ }^{*}$ F. J. Schwarz,† R. Ringseis, ${ }^{*}$ and K. Eder*1 \\ *Institute of Animal Nutrition and Nutrition Physiology, Justus-Liebig-University Giessen, Heinrich-Buff-Ring 26-32, 35392 Giessen, Germany \\ †Chair of Animal Nutrition, Center of Life and Food Sciences Weihenstephan, Technische Universität München, Liesel-Beckmann-Strasse 6, \\ 85350 Freising-Weihenstephan, Germany
}

\begin{abstract}
In the liver of dairy cows, the production of cytokines is enhanced during the periparturient phase, which in turn leads to inflammation and an impairment of hepatic function. Nuclear factor E2-related factor 2 (Nrf2) is a redox-sensitive transcription factor that controls the transcription of genes encoding various antioxidative and cytoprotective proteins. In the present study, we investigated the hypothesis that Nrf2 is activated in the liver of dairy cows during the periparturient phase to protect the liver against the deleterious effects of cytokines and reactive oxygen species. Therefore, we determined relative mRNA abundances of TNF (encoding tumor necrosis factor- $\alpha$ ), various acute phase proteins and several Nrf2 target genes in liver biopsy samples of 20 dairy cows at each time point from 3 wk antepartum to 1,5 , and 14 wk postpartum. We observed an increase in mRNA abundances of TNF and acute-phase proteins [serum amyloid A $3(S A A 3)$, haptoglobin $(H P)$, and Creactive protein $(C R P)]$ from $3 \mathrm{wk}$ antepartum to $1 \mathrm{wk}$ postpartum, indicative of a proinflammatory condition. Messenger RNA abundances of various Nrf2 target genes with antioxidative or cytoprotective functions glutathione peroxidase 3 (GPX3); microsomal glutathione S-transferase 3 (MGST3); superoxide dismutase (SOD1); catalase $(C A T)$; metallothioneins $1 \mathrm{~A}, 1 \mathrm{E}$, and 2A (MT1A, MT1E, and MT2A, respectively); NAD(P) $\mathrm{H}$ dehydrogenase, quinone 1 (NQO1); heme oxygenase 2 (HMOX2); and UDP glucuronosyltransferase 1 family, polypeptide A1 (UGT1A1)] were also greatly increased from 3 wk antepartum to 1 wk postpartum. From 1 wk postpartum to later lactation, mRNA abundances of all the Nrf2-target genes considered declined but remained at levels that were higher than those in $3 \mathrm{wk}$ antepartum. No correlations were found, however, between plasma concentrations of nonesterified fatty acids or $\beta$-hydroxybutyrate and mRNA abundances of Nrf2 target genes, indicating that a negative energy balance
\end{abstract}

Received July 21, 2012.

Accepted November 6, 2012.

${ }^{1}$ Corresponding author: klaus.eder@ernaehrung.uni-giessen.de might not have been the main factor responsible for upregulation of those genes in the liver during early lactation. In conclusion, this study provides additional evidence that the periparturient phase in dairy cows is associated with a proinflammatory condition in the liver. Moreover, it is shown for the first time that the transition from pregnancy to lactation leads to a strong upregulation of Nrf2 target genes with antioxidative or cytoprotective properties, which might be another physiologic means to prevent the liver against damage by the inflammation process and an increased generation of reactive oxygen species.

Key words: dairy cow, transition period, liver, inflammation, nuclear factor E2-related factor 2 (Nrf2)

\section{INTRODUCTION}

During the periparturient phase, dairy cows are typically in an inflammatory-like condition (Bertoni et al., 2008; Sordillo et al., 2009; Trevisi et al., 2010, 2012). Inflammation is generally induced by the release of proinflammatory mediators such as cytokines through leukocytes or tissue cells, which promote both a local and a systemic response such as fever, anorexia, endocrine, or metabolic changes, leading to catabolism. In the liver, cytokines lead to the production of acute-phase proteins such as serum amyloid A (SAA), haptoglobin $(\mathbf{H P})$, or C-reactive protein (CRP), which compete with the production of essential liver proteins such as albumins, enzymes, lipoproteins, or carriers of vitamins and hormones. Thus, inflammation impairs liver function. This is particularly a problem when the liver is metabolically overcharged such as in the periparturient phase (Bertoni et al., 2008; Trevisi and Bertoni, 2008). During this phase, fat and protein body stores are mobilized to cover the energy deficiency, and the liver is responsible for gluconeogenesis and FA metabolism.

The liver possesses a system that protects it against the deleterious effects of reactive oxygen species (ROS) or xenobiotic compounds. This system, consisting of phase I and II enzymes, is regulated by various transcription factors of which nuclear factor E2-related fac- 
tor 2 (Nrf2) is the most important one. Nuclear factor E2-related factor 2 is a redox-sensitive transcription factor that controls the transcription of various antioxidative and cytoprotective proteins. Activation of Nrf2 not only reduces the sensitivity of tissues to oxidative damage and cytotoxicity but also suppresses proinflammatory signaling, attenuates inflammatory damage, and neutralizes ROS produced under proinflammatory conditions (Köhle and Bock, 2007; Baird and DinkovaKostova, 2011). Based on its antiinflammatory and cytoprotective functions, it has been suggested that Nrf2 counteracts proinflammatory signaling pathways (Kim et al., 2010). It has been shown that chemical signals resulting from inflammation, such as ROS, activate Nrf2 by releasing it from Keap-1 (Nair et al., 2008). Based on this interaction, we hypothesized that the proinflammatory conditions in the liver of dairy cows in the periparturient phase might be associated with an activation of Nrf2, which could be a means to protect the liver against damage. To investigate this hypothesis, we determined mRNA abundances of various Nrf2 target genes in liver biopsy samples of dairy cows in the periparturient phase and during lactation.

\section{MATERIALS AND METHODS}

For this investigation, liver biopsy samples from a recent trial with dairy cows performed at the Agricultural Experimental Station Hirschau of the Technical University of Munich, Germany, which was described in detail by Schlegel et al. (2012b), were used. All procedures for this trial were approved by the Bavarian state animal care and use committee. The trial included 20 Holstein cows (4 primi- and 16 multiparous; parities of $2.7 \pm 1.1$, mean $\pm \mathrm{SD}$ ) as experimental animals with an experimental period from 3 wk antepartum to 14 wk postpartum. The animals were housed in a freestall barn. They received a partial mixed ration for ad libitum intake of basic feed, with separate and limited intake of concentrates. Liver biopsies were taken from the right liver lobe (lobus hepatis dexter) at 3 wk antepartum, and 1, 5, and $14 \mathrm{wk}$ postpartum before feeding between 0700 and $0900 \mathrm{~h}$.

Total RNA isolation from liver biopsies, cDNA synthesis, and real-time quantitative PCR were carried out as described recently in detail (Schlegel et al., 2012b). The RNA concentration and purity were estimated from the optical density at 260 and $280 \mathrm{~nm}$, respectively, using an Infinite $200 \mathrm{M}$ microplate reader and a NanoQuant Plate (both from Tecan Group Ltd., Männedorf, Switzerland). The A260/A280 (absorbance at the wavelengths of $260 \mathrm{~nm}$ and $280 \mathrm{~nm}$ ) ratios were $2.02 \pm$ 0.05 , representing all animals. The integrity of the total RNA was checked by $1 \%$ agarose gel electrophoresis and judged as suitable for quantitative PCR only if the samples exhibited intact bands corresponding to the $18 \mathrm{~S}$ and $28 \mathrm{~S}$ ribosomal RNA subunits. Expression values of the genes investigated were normalized using the geNorm normalization factor according to Vandesompele et al. (2002). The procedure of normalization and average expression stability ranking of the 6 potential reference genes in liver of cows were also performed as described recently (Schlegel et al., 2012b). The characteristics of gene-specific primers are shown in Table 1. After normalization of gene expression data using the calculated geNorm normalization factor, means and standard error of the mean were calculated from normalized expression data for samples of the same treatment group. The mean of $3 \mathrm{wk}$ antepartum was set to $1 \pm$ standard error of the mean and relative expression ratios of 1, 5, and 14 wk postpartum are expressed as fold changes compared with 3 wk antepartum.

Data were analyzed with PROC MIXED of SAS software (version 9.2; SAS Institute Inc., Cary, NC) including time and parity ( 1 or $\geq 2)$ as fixed effects and cow as random effect. Multiple comparisons between the means at each sampling time point were performed by the Bonferroni $t$-test, and differences between means were considered significant for $P<0.05$. Correlations are expressed as Pearson correlation coefficients on raw data of metabolic parameters and relative mRNA abundances using PROC CORR in SAS. A correlation was considered as statistically significant for $P<0.05$.

\section{RESULTS}

Performance parameters of cows used in this experiment have recently been reported (Schlegel et al., 2012b). Milk yield of the cows, on average from wk 1 to 14 , was around $33 \mathrm{~kg} / \mathrm{d}$, and average feed intake was $18.5 \mathrm{~kg}$ of $\mathrm{DM} / \mathrm{d}$. The onset of lactation led to a strong negative energy balance (NEB) transition of around $-65 \mathrm{MJ}$ of $\mathrm{NE}_{\mathrm{L}} / \mathrm{d}$ in wk 1 . At 14 wk postpartum, the cows returned to a slight positive energy balance. In accordance with the strong NEB during early lactation, concentrations of NEFA and BHBA in plasma greatly increased from $3 \mathrm{wk}$ antepartum to $1 \mathrm{wk}$ postpartum and declined thereafter until wk 14 postpartum (Schlegel et al., 2012a). Liver triacylglycerol (TAG) concentration increased with the onset of lactation, reached its maximum at 5 wk postpartum, and declined thereafter (Schlegel et al., 2012a).

\section{Relative mRNA Abundances of Inflammatory Genes in the Liver}

To assess the inflammatory status of the liver, we determined relative mRNA abundances of TNF and 
Table 1. Characteristics of gene-specific primers used for quantitative PCR

\begin{tabular}{|c|c|c|c|}
\hline Gene $^{1}$ & $\begin{array}{l}\text { Forward primer (from } 5^{\prime} \text { to } 3^{\prime} \text { ) } \\
\text { and reverse primer (from } 5^{\prime} \text { to } 3^{\prime} \text { ) }\end{array}$ & $\begin{array}{l}\text { PCR product } \\
\text { size (bp) }\end{array}$ & $\begin{array}{l}\text { NCBI GenBank }{ }^{2} \\
\text { accession no. }\end{array}$ \\
\hline \multicolumn{4}{|c|}{ Reference gene } \\
\hline$A T P 5 B$ & GGACTCAGCCCTTCAGCGCC & 229 & NM_175796.2 \\
\hline \multirow{2}{*}{ PPIA } & GGCAAATGCTGGCCCCAACACA & 87 & NM_ 178320.2 \\
\hline & AGTACCACGTGCTTGCCATCCA & & \\
\hline \multirow[t]{2}{*}{ RPL12 } & CACCAGCCGCCTCCACCATG & 84 & NM_205797.1 \\
\hline & CGACTTCCCCACCGGTGCAC & & \\
\hline \multirow{3}{*}{$\begin{array}{l}\text { Target gene } \\
C A T\end{array}$} & & & \\
\hline & TGGGACCCAACTATCTCCAG & 178 & NM_001035386.1 \\
\hline & AAGTGGGTCCTGTGTTCCAG & & \\
\hline \multirow[t]{2}{*}{$C R P$} & GGCCAGACAGACTTGCATAAGAAGG & 142 & NM_001144097.1 \\
\hline & GGGTTCGGGCCAGCTCTGTG & & \\
\hline \multirow[t]{2}{*}{$G P X 3$} & ACCACCGCACCACGGTCAAC & 127 & NM_174077.3 \\
\hline & GCCCGTGTGGTGGACTTGGG & & \\
\hline \multirow[t]{2}{*}{ MGST3 } & GGGCTTGGCCTGGATCGTTGG & 124 & NM_001035046.1 \\
\hline & CACAGTGGTGCCCATCAGGCC & & \\
\hline \multirow[t]{2}{*}{$H P$} & CCTCAAGGAAGCTGGTCAAGGGGCT & 144 & NM_001040470.1 \\
\hline & TGAGGCAGTGTGCGGGAAGCC & & \\
\hline \multirow{2}{*}{$H M O X 2$} & GCCACCACCGCGCTGTACTT & 108 & NM_001035087.2 \\
\hline & CCGGTGTAGCTCCGTGGGGA & & \\
\hline \multirow[t]{2}{*}{ SOD1 } & TGTTGCCATCGTGGATATTG & 143 & NM_174615.2 \\
\hline & CAGCGTTGCCAGTCTTTGTA & & \\
\hline \multirow[t]{2}{*}{$M T 1 A$} & ATCCGACCAGTGGATCTGCTTTGCC & 209 & NM_001040492.2 \\
\hline & AGACACAGCCCTGGGCACACT & & \\
\hline \multirow[t]{2}{*}{$M T 1 E$} & ACGACCACACTTCGTCTCCGAA & 261 & NM_001114857.1 \\
\hline & ATGCAGGTTGGCCCACGTTCC & & \\
\hline \multirow[t]{2}{*}{ MT2A } & GACCCCAGCCTCCAGTTCAGCTC & 93 & NM_001075140.1 \\
\hline & CTTTGCATTTGCAGGAGCCGGC & & \\
\hline \multirow[t]{2}{*}{ NQO1 } & AACCAACAGACCAGCCAATC & 146 & NM_001034535.1 \\
\hline & ССТСССАТССТТТССТСТТС & & \\
\hline \multirow[t]{2}{*}{$S A A 3$} & CCTCAAGGAAGCTGGTCAAGGGGCT & 141 & NM_181016.3 \\
\hline & CAGGCACCCCCAGGTCCCCT & & \\
\hline \multirow[t]{2}{*}{$T N F$} & GCCCCCAGGGCTCCAGAAGTT & 134 & NM_173966.2 \\
\hline & GCCACCTGGGGACTGCTCTTCC & & \\
\hline \multirow[t]{2}{*}{$U G T 1 A 1$} & GCTCGTCAAGTGGCTGCCCCA & 175 & NM_001105636.1 \\
\hline & TCCCCGGGTCTCCATGCGCT & & \\
\hline \multicolumn{4}{|c|}{$\begin{array}{l}{ }^{1} A T P 5 B=\text { ATP synthase, } \mathrm{H}^{+} \text {transporting, mitochondrial } \mathrm{F} 1 \text { complex, } \beta \text { polypeptide; } C A T=\text { catalase; } C R F \\
=\text { C-reactive protein; GPX } 3=\text { glutathione peroxidase } 3 ; H M O X 2=\text { heme oxygenase } 2 ; H P=\text { haptoglobin } \\
M G S T 3=\text { microsomal glutathione S-transferase } 3 ; M T 1 A=\text { metallothionein } 1 \mathrm{~A} ; M T 1 E=\text { metallothionein } 1 \mathrm{E} \\
M T 2 A=\text { metallothionein } 2 \mathrm{~A} ; N Q O 1=\mathrm{NAD}(\mathrm{P}) \mathrm{H} \text { dehydrogenase, quinone } 1 ; P P I A=\text { peptidylprolyl isomerase } \\
\mathrm{A} ; R P L 12=\text { ribosomal protein } \mathrm{L} 12 ; S A A 3=\text { serum amyloid } \mathrm{A} 3 ; S O D 1=\text { superoxide dismutase } 1 ; \text { TNF }= \\
\text { tumor necrosis factor; } U G T 1 A 1=\mathrm{UDP} \text { glucuronosyltransferase } 1 \text { family, polypeptide A1. }\end{array}$} \\
\hline \multicolumn{4}{|c|}{ ²National Center for Biotechnology Information (NCBI) database (http://www.ncbi.nlm.nih.gov/genbank/). } \\
\hline
\end{tabular}

the acute-phase proteins $S A A 3, H P$, and $C R P$. Relative mRNA abundance of TNF moderately (1.8-fold) increased from $3 \mathrm{wk}$ antepartum to $1 \mathrm{wk}$ postpartum $(P<0.05)$, whereas mRNA abundances of the 3 acute-phase proteins greatly (4- to 20 -fold) increased $(P<0.05$; Table 2$)$. From 1 wk postpartum to later lactation, mRNA abundances of all these genes declined (Table 2). Whereas mRNA abundances of $C R P$ and $S A A 3$ were also elevated in wk 5 and 14 postpartum compared with 3 wk antepartum $(P<$ 0.05 ), mRNA abundances of TNF and HP returned to levels that were not different from 3 wk antepartum (Table 2).

\section{Relative mRNA Abundances of Nrf2 Target Genes in the Liver}

To assess Nrf2 signaling in the liver during the periparturient phase, we determined relative hepatic mRNA abundances of various Nrf2 target genes encoding proteins with antioxidative properties [such as glutathione peroxidase 3 (GPX3), microsomal glutathione S-transferase 3 (MGST3), superoxide dismutase $(S O D 1)$, catalase $(C A T)$, and metallothioneins $(M T)$ $1 \mathrm{~A}, 1 \mathrm{E}$, and $2 \mathrm{~A}$ ] or detoxifying functions [such as NAD $(\mathrm{P}) \mathrm{H}$ dehydrogenase, quinone 1 (NQO1); heme oxygenase 2 (HMOX2); and UDP glucuronosyltransferase 
Table 2. Relative mRNA abundances of inflammatory genes and nuclear factor E2-related factor 2 (Nrf2) target genes in the liver of Holstein cows at 3 wk antepartum and 1, 5, and 14 wk postpartum ${ }^{1}$

\begin{tabular}{|c|c|c|c|c|c|}
\hline Gene $^{2}$ & $\begin{array}{c}3 \mathrm{wk} \\
\text { antepartum }\end{array}$ & $\begin{array}{c}1 \mathrm{wk} \\
\text { postpartum }\end{array}$ & $\begin{array}{c}5 \mathrm{wk} \\
\text { postpartum }\end{array}$ & $\begin{array}{c}14 \mathrm{wk} \\
\text { postpartum }\end{array}$ & $P$-value \\
\hline \multicolumn{6}{|c|}{ Inflammatory gene } \\
\hline$T N F$ & $1.00 \pm 0.23^{\mathrm{a}}$ & $1.75 \pm 0.21^{\mathrm{b}}$ & $1.59 \pm 0.21^{\mathrm{b}}$ & $1.25 \pm 0.15^{\mathrm{a}}$ & 0.044 \\
\hline$C R P$ & $1.00 \pm 0.23^{\mathrm{a}}$ & $3.86 \pm 0.59^{\mathrm{b}}$ & $2.80 \pm 0.27^{\mathrm{b}}$ & $3.40 \pm 1.52^{\mathrm{b}}$ & 0.0029 \\
\hline$H P$ & $1.00 \pm 0.29^{\mathrm{a}}$ & $19.67 \pm 2.55^{\mathrm{b}}$ & $1.04 \pm 0.40^{\mathrm{a}}$ & $0.93 \pm 0.23^{\mathrm{a}}$ & $<0.0001$ \\
\hline$S A A 3$ & $1.00 \pm 0.18^{\mathrm{a}}$ & $13.26 \pm 1.90^{\mathrm{c}}$ & $2.37 \pm 0.24^{\mathrm{b}}$ & $4.03 \pm 0.68^{\mathrm{b}}$ & $<0.0001$ \\
\hline \multicolumn{6}{|c|}{ Nrf2 target gene } \\
\hline$C A T$ & $1.00 \pm 0.24^{\mathrm{a}}$ & $6.10 \pm 0.82^{\mathrm{c}}$ & $4.36 \pm 0.53^{\mathrm{b}}$ & $4.03 \pm 0.70^{\mathrm{b}}$ & $<0.0001$ \\
\hline$G P X 3$ & $1.00 \pm 0.24^{\mathrm{a}}$ & $26.24 \pm 8.85^{\mathrm{c}}$ & $4.41 \pm 0.58^{\mathrm{b}}$ & $3.37 \pm 0.54^{\mathrm{b}}$ & 0.0092 \\
\hline MGST3 & $1.00 \pm 0.19^{\mathrm{a}}$ & $4.78 \pm 0.40^{\mathrm{c}}$ & $2.97 \pm 0.27^{\mathrm{b}}$ & $2.33 \pm 0.37^{\mathrm{b}}$ & $<0.0001$ \\
\hline$H M O X 2$ & $1.00 \pm 0.24^{\mathrm{a}}$ & $3.52 \pm 0.39^{c}$ & $1.88 \pm 0.31^{\mathrm{b}}$ & $1.59 \pm 0.30^{\mathrm{ab}}$ & $<0.0001$ \\
\hline$M T 1 A$ & $1.00 \pm 0.24^{\mathrm{a}}$ & $39.37 \pm 6.2^{\mathrm{c}}$ & $16.80 \pm 3.36^{\mathrm{b}}$ & $13.18 \pm 3.76^{\mathrm{b}}$ & 0.0007 \\
\hline$M T 1 E$ & $1.00 \pm 0.20^{\mathrm{a}}$ & $171.16 \pm 33.36^{\mathrm{c}}$ & $24.23 \pm 4.84^{\mathrm{b}}$ & $24.74 \pm 7.37^{\mathrm{b}}$ & $<0.0001$ \\
\hline MT2A & $1.00 \pm 0.22^{\mathrm{a}}$ & $20.07 \pm 2.84^{\mathrm{c}}$ & $7.61 \pm 1.13^{\mathrm{b}}$ & $7.86 \pm 1.61^{\mathrm{b}}$ & $<0.0001$ \\
\hline$N Q O 1$ & $1.00 \pm 0.26^{\mathrm{a}}$ & $5.50 \pm 0.63^{\mathrm{c}}$ & $4.16 \pm 0.63^{\mathrm{bc}}$ & $3.20 \pm 0.44^{\mathrm{b}}$ & 0.0003 \\
\hline SOD1 & $1.00 \pm 0.24^{\mathrm{a}}$ & $5.99 \pm 0.72^{\mathrm{c}}$ & $3.33 \pm 0.39^{\mathrm{b}}$ & $2.68 \pm 0.44^{b}$ & $<0.0001$ \\
\hline$U G T 1 A 1$ & $1.00 \pm 0.23^{\mathrm{a}}$ & $10.50 \pm 1.07^{\mathrm{c}}$ & $4.56 \pm 0.23^{\mathrm{b}}$ & $4.11 \pm 0.97^{\mathrm{b}}$ & $<0.0001$ \\
\hline
\end{tabular}

${ }^{\mathrm{a}-\mathrm{c}}$ Means within a row with different superscripts differ significantly $(P<0.05)$.

${ }^{1}$ Messenger RNA abundances of genes are expressed relative to the mRNA abundance at 3 wk antepartum. Values are means \pm SEM $(\mathrm{n}=20)$.

${ }^{2} C A T=$ catalase $C R P=$ C-reactive protein $G P X 3=$ glutathione peroxidase $3 ; H M O X 2=$ heme oxygenase 2; $H P=$ haptoglobin; $M G S T 3=$ microsomal glutathione S-transferase 3; $M T 1 A=$ metallothionein-1A; MT1E $=$ metallothionein $1 \mathrm{E} ; M T 2 A=$ metallothionein $2 \mathrm{~A} ; N Q O 1=\mathrm{NAD}(\mathrm{P}) \mathrm{H}$ dehydrogenase, quinone $1 ; S A A 3=$ serum amyloid A 3; SOD1 = superoxide dismutase 1; TNF = tumor necrosis factor; UGT1A1 = UDP glucuronosyltransferase 1 family, polypeptide A1.

1 family, polypeptide A1 (UGT1A1)]. Relative mRNA abundances of all those genes greatly increased from 3 wk antepartum to 1 wk postpartum $(P<0.05$; Table 2). From 1 wk postpartum to later lactation, mRNA abundances of all these Nrf2 target genes declined but remained at levels that were in excess of those at $3 \mathrm{wk}$ antepartum $(P<0.05$; Table 2$)$.

\section{Correlations Between Metabolites and mRNA Abundances of Inflammatory and Nrf2 Target Genes}

To investigate potential associations between the metabolic status of the cows and the expression of inflammatory and Nrf2 target genes, Pearson correlation analysis between plasma NEFA concentration, plasma BHBA concentration, or liver TAG concentration and the relevant genes (TNF, SAA3, HP, CRP, GPX3, MGST3, SOD1, CAT, MT1A, MT1E, MT2A, NQO1, HMOX2, and UGT1A1) at the 4 time points of sampling was performed. Overall, only a few significant correlations existed between the metabolic parameters and mRNA abundances of the genes considered. At 3 wk antepartum and $1 \mathrm{wk}$ postpartum, no significant correlations were observed between plasma NEFA concentration, plasma BHBA concentration, or liver TAG concentration and mRNA abundance of any of the genes considered. At 5 wk postpartum, positive correlations were found between plasma NEFA concentration and mRNA abundance of $S A A 3(\mathrm{r}=0.58$,
$P<0.05)$ and between liver TAG concentration and mRNA abundance of GPX3 $(\mathrm{r}=0.59 ; P<0.05)$. At 14 wk postpartum, a positive correlation existed between plasma NEFA concentration and mRNA abundance of $M T 1 E(\mathrm{r}=0.68 ; P<0.05)$.

\section{DISCUSSION}

In dairy cows, the onset of lactation typically leads to a strong NEB due to the high energy requirement for milk production, which cannot be met by food intake (Drackley, 1999). Studies using transcriptomic and proteomic analyses have shown that NEB in dairy cows leads to dramatic alterations of many biochemical pathways in the liver (Loor et al., 2007; Kuhla et al., 2009; McCarthy et al., 2010; McCabe et al., 2012). In the last years, it has become more and more apparent that dairy cows are in a proinflammatory condition during the periparturient phase (Bertoni et al., 2008; Sordillo et al., 2009; Trevisi et al., 2010, 2012). Systemic inflammation in periparturient dairy cows may be caused by various events such as injuries and trauma during calving, mammary gland edema, uterus involution, infectious or metabolic diseases, parasites, or endotoxins from the gut (Trevisi and Bertoni, 2008; Zebeli and Metzler-Zebeli, 2012). Studies in dairy cows that were subjected to feed restriction, however, show that NEB contributes to the induction of hepatic inflammation (Loor et al., 2007; McCarthy et al., 2010). 
The present study, performed with Holstein cows that were in a strong NEB during early lactation, confirms that the transition from late pregnancy to early lactation in dairy cows is associated with a proinflammatory condition in the liver. This is evident by an induction of $T N F$, one of the most important cytokines and a hallmark of inflammation, and increased mRNA abundances of acute phase proteins in the liver. In contrast to the study of Loor et al. (2005), we found less correlation between plasma concentrations of NEFA and BHBA or liver TAG concentration and the expression of inflammatory genes. This suggests that NEB might not have been the main factor responsible for the proinflammatory condition in the liver in the cows used in this study. It has been shown that the proinflammatory condition adversely affects liver function and that proinflammatory cytokines are, at least in part, responsible for the liver dysfunction in the periparturient phase (Bertoni et al., 2008; Bradford et al., 2009). The adverse effects of proinflammatory conditions in dairy cows have been demonstrated in a study in which cows were orally treated with acetylsalicylate during the first week of lactation. In that study, treatment with the antiinflammatory drug not only lowered plasma inflammatory markers but also improved liver function, milk yield, SCC, and reproductive performance (Trevisi and Bertoni, 2008).

Nuclear factor E2-related factor 2 has been identified as a transcription factor that controls the transcription of various antioxidative and cytoprotective proteins, which protects tissues against the deleterious effects of ROS, proinflammatory cytokines, and xenobiotics (Itoh et al., 1997). In the present study, we observed for the first time that the expression of several Nrf2 target genes in the liver of dairy cows is strongly upregulated during early lactation. For technical reasons (due to the small sample size of biopsies), we were not able to determine activities of antioxidant enzymes or the antioxidant capacity of the liver. However, as most of the genes upregulated by Nrf2 have antioxidative activity, it is highly probable that the antioxidative capacity of the liver was increased during the transition from pregnancy to lactation.

Nuclear factor E2-related factor 2 can be activated by various factors, such as xenobiotics, heavy metals, antioxidants, electrophiles, or ROS (Kaspar et al., 2009). These compounds lead to a release of Nrf2 from Keap-1, an inhibitory protein, which allows Nrf2 to translocate to the nucleus where it enhances the transcription of genes containing an antioxidant response element in their promoters as target structure (Köhle and Bock, 2007; Baird and Dinkova-Kostova, 2011). Thus, the finding that the expression of the Nrf2 target genes considered in this study, which all possess an antioxidant response element in their promoters, was increased, indicates that Nrf2 was activated in the liver during early lactation. Although we do not have direct evidence for this, it is likely that ROS, produced in the course of the inflammatory process and by an increased energy production through the electron transport chain, might be mainly responsible for activation of Nrf2.

During early lactation, dairy cows are indeed subjected to oxidative stress, as shown by increased concentrations of reactive oxygen metabolites in plasma (Bionaz et al., 2007). Thus, oxidative stress could have induced the activation of Nrf2 observed in this study. To our knowledge, the expression of Nrf2 target genes in the liver of dairy cows in the periparturient phase has not yet been investigated. One study, however, found that a severe NEB in early lactating cows, compared with a moderately NEB, leads to an upregulation of several Nrf2 target genes with antioxidative properties in the spleen (Morris et al., 2009). The authors of that study suggested that the upregulation of these genes might be a response to mitigate or reduce the damaging effect of increased concentrations of ROS in the spleen produced during strong NEB. Due to its important functions in the regulation of antioxidative and cytoprotective functions, Nrf2 might be generally an important target for protecting tissues against the deleterious effects of proinflammatory cytokines and ROS. In this study, we observed that Nrf2 in the liver is activated during early lactation, probably as a means to protect the liver against damage. It has been shown that activation of Nrf2 can also be induced by dietary components such as polyphenols (Rahman et al., 2006). Therefore, dietary strategies could also be helpful to improve the protection of tissues against deleterious cellular events during early lactation. Interestingly, we did not observe correlations between plasma concentrations of NEFA or BHBA and mRNA abundances of Nrf2 target genes, which indicates that NEB might not have been the main factor responsible for upregulation of those genes in the liver during early lactation.

\section{CONCLUSIONS}

The present study shows for the first time that Nrf2 target genes involved in antioxidant defense and cytoprotection in the liver are upregulated during early lactation in dairy cows. This observation indicates an activation of Nrf2, which might be a physiologic means to counteract the inflammatory process and to prevent the liver against damage induced by inflammation and ROS production. Prevention of liver damage induced by inflammation is not only important for maintaining liver function but also for general health of high-yielding dairy cows (Drackley, 1999). Thus, Nrf2 could be 
an important target for maintaining liver function and improving general health in high-yielding dairy cows.

\section{ACKNOWLEDGMENTS}

G. Schlegel was supported by a scholarship from the H. Wilhelm Schaumann Stiftung (Hamburg, Germany).

\section{REFERENCES}

Baird, L., and A. T. Dinkova-Kostova. 2011. The cytoprotective role of the Keap1-Nrf2 pathway. Arch. Toxicol. 85:241-272.

Bertoni, G., E. Trevisi, X. Han, and M. Bionaz. 2008. Effects of inflammatory conditions on liver activity in puerperium period and consequences for performance in dairy cows. J. Dairy Sci. 91:3300-3310.

Bionaz, M., E. Trevisi, L. Calamari, F. Librandi, A. Ferrari, and G. Bertoni. 2007. Plasma paraoxonase, health, inflammatory conditions, and liver function in transition dairy cows. J. Dairy Sci. 90:1740-1750.

Bradford, B. J., L. K. Mamedova, J. E. Minton, J. S. Drouillard, and B. J. Johnson. 2009. Daily injection of tumor necrosis factor- $\alpha$ increases hepatic triglycerides and alters transcript abundance of metabolic genes in lactating dairy cattle. J. Nutr. 139:1451-1456.

Drackley, J. K. 1999. Biology of dairy cows during the transition period: The final frontier? J. Dairy Sci. 82:2259-2273.

Itoh, K., T. Chiba, S. Takahashi, T. Ishii, K. Igarashi, Y. Katoh, T. Oyake, N. Hayashi, K. Satoh, I. Hatayama, M. Yamamoto, and Y. Nabeshima. 1997. An Nrf2/small Maf heterodimer mediates the induction of phase II detoxifying enzyme genes through antioxidant response elements. Biochem. Biophys. Res. Commun. 236:313-322.

Kaspar, J. W., S. K. Niture, and A. K. Jaiswal. 2009. Nrf2:INrf2 (Keap1) signaling in oxidative stress. Free Radic. Biol. Med. 47:1304-1309.

Kim, J., Y.-N. Cha, and Y.-J. Surh. 2010. A protective role of nuclear factor-erythroid 2-related factor-2 (Nrf2) in inflammatory disorders. Mutat. Res. 690:12-23.

Köhle, C., and K. W. Bock. 2007. Coordinate regulation of phase I and II xenobiotic metabolism by the Ah receptor and Nrf2. Biochem. Pharmacol. 73:1853-1862.

Kuhla, B., D. Albrecht, S. Kuhla, and C. C. Metges. 2009. Proteome analysis of fatty liver in feed-deprived dairy cows reveals interaction of fuel sensing, calcium, fatty acid, and glycogen metabolism. Physiol. Genomics 37:88-98.

Loor, J. J., H. M. Dann, R. E. Everts, R. Oliveira, C. A. Green, N. A. Guretzky, S. L. Rodriguez-Zas, H. A. Lewin, and J. K. Drackley. 2005. Temporal gene expression profiling of liver from periparturient dairy cows reveals complex adaptive mechanisms in hepatic function. Physiol. Genomics 23:217-226.

Loor, J. J., R. E. Everts, M. Bionaz, H. M. Dann, D. E. Morin, R. Oliveira, S. L. Rodriguez-Zas, J. K. Drackley, and H. A. Lewin.
2007. Nutrition-induced ketosis alters metabolic and signaling gene networks in liver of periparturient dairy cows. Physiol. Genomics 32:105-116.

McCabe, M., S. Waters, D. Morris, D. Kenny, D. Lynn, and C. Creevey. 2012. RNA-seq analysis of differential gene expression in liver from lactating dairy cows divergent in negative energy balance. BMC Genomics 13:193.

McCarthy, S. D., S. M. Waters, D. A. Kenny, M. G. Diskin, R. Fitzpatrick, J. Patton, D. C. Wathes, and D. G. Morris. 2010. Negative energy balance and hepatic gene expression patterns in highyielding dairy cows during the early postpartum period: A global approach. Physiol. Genomics 42A:188-199.

Morris, D. G., S. M. Waters, S. D. McCarthy, J. Patton, B. Earley, R. Fitzpatrick, J. J. Murphy, M. G. Diskin, D. A. Kenny, A. Brass, and D. C. Wathes. 2009. Pleiotropic effects of negative energy balance in the post-partum dairy cow on splenic gene expression: Repercussions for innate and adaptive immunity. Physiol. Genomics 39:28-37.

Nair, S., S. T. Doh, J. Y. Chan, A.-N. Kong, and L. Cai. 2008. Regulatory potential for concerted modulation of Nrf2- and Nfkb1-mediated gene expression in inflammation and carcinogenesis. Br. J. Cancer 99:2070-2082.

Rahman, I., S. K. Biswas, and P. A. Kirkham. 2006. Regulation of inflammation and redox signaling by dietary polyphenols. Biochem. Pharmacol. 72:1439-1452.

Schlegel, G., J. Keller, F. Hirche, S. Geißler, F. J. Schwarz, R. Ringseis, G. I. Stangl, and K. Eder. 2012a. Expression of genes involved in hepatic carnitine synthesis and uptake in dairy cows in the transition period and at different stages of lactation. BMC Vet. Res. 8:28.

Schlegel, G., R. Ringseis, J. Keller, F. J. Schwarz, and K. Eder. 2012b. Changes in the expression of hepatic genes involved in cholesterol homeostasis in dairy cows in the transition period and at different stages of lactation. J. Dairy Sci. 95:3826-3836.

Sordillo, L. M., G. A. Contreras, and S. L. Aitken. 2009. Metabolic factors affecting the inflammatory response of periparturient dairy cows. Anim. Health Res. Rev. 10:53-63.

Trevisi, E., M. Amadori, S. Cogrossi, E. Razzuoli, and G. Bertoni. 2012. Metabolic stress and inflammatory response in high-yielding, periparturient dairy cows. Res. Vet. Sci. 93:695-704.

Trevisi, E., and G. Bertoni. 2008. Attenuation with acetylsalicylate treatments of inflammatory conditions in periparturient dairy cows. Pages 22-37 in Aspirin and Health Research Progress. P. I. Quinn, ed. Nova Science Publishers, New York, NY.

Trevisi, E., A. Zecconi, G. Bertoni, and R. Piccinini. 2010. Blood and milk immune and inflammatory profiles in periparturient dairy cows showing a different liver activity index. J. Dairy Res. $77: 310-317$.

Vandesompele, J., K. De Preter, F. Pattyn, B. Poppe, N. Van Roy, A. De Paepe, and F. Speleman. 2002. Accurate normalization of realtime quantitative RT-PCR data by geometric averaging of multiple internal control genes. Genome Biol. 3:RESEARCH0034.

Zebeli, Q., and B. U. Metzler-Zebeli. 2012. Interplay between rumen digestive disorders and diet-induced inflammation in dairy cattle. Res. Vet. Sci. 93:1099-1108. 